\title{
ENZYMATIC CHARACTERIZATION OF YEAST ISOLATED FROM NATURALLY FERMENTED HERBS*
}

\author{
Erkan Güneş ${ }^{1}$, Furkan Aydın ${ }^{2}$ İbrahim Çakır ${ }^{3 * *}$ \\ ${ }^{1}$ Amasya University Rectorate, Internal Audit Unit, Amasya, Turkey, \\ ${ }^{2}$ Aksaray University, Faculty of Engineering, Food Engineering Department, Aksaray, Turkey. \\ ${ }^{3}$ Bolu Abant İzzet Baysal University, Faculty of Engineering, Food Engineering Department, Bolu, Turkey. \\ Received/ Geliş: 17.05.2021; Accepted/ Kabul: 06.07.2021; Published online/ Online bask1: 02.08.2021 \\ Günes, E., Aydin, F., Cakir, İ. (2021). Ensymatıc characterızatıon of yeast isolated from naturally fermented herbs. \\ GIDA (2021) 46 (5) 1081-1091 doi: 10.15237/gida.GD21088
}

Güneş, E., Aydın, F., Çakır, İ. (2021). Enzymatic characterization of yeast isolated from naturally fermented herbs. GIDA (2021) 46 (5) 1081-1091 doi: 10.15237/gida.GD21088

\begin{abstract}
This study aims to identify yeasts from spontaneously fermented herbs used for Van herby cheese and to evaluate their enzymatic activities. Sequencing of partial 26S rRNA gene revealed the species of Pichia membranifaciens $(n=8)$, Kazacbstania servazzii $(n=6)$, Debaryomyces bansenii $(n=2)$, Kluyveromyces marxianus $(n=$ 2), and Picbia fermentans $(n=2)$. Enzyme profiles were determined using API-ZYM strips. The isolates had diverse enzyme activities, including alkaline and acid phosphatase, esterase, esterase lipase, aminopeptidases, and proteases mostly at different levels, which may have crucial roles during ripening of the cheese. $K$. marxianus M8.1, D. bansenii M6.1, and M6.3, P. membraniciens M13.1, M13.2, and M14.1 had superior and diverse enzymatic characteristics. Such enzymatic activities could be of great technological importance for the determination of adjunct culture along with starter lactic acid bacteria for the production of Van herby cheese.
\end{abstract}

Keywords: Brine solution, herb, yeast, enzyme activity.

\section{FERMENTE SALAMURA OTLARDAN IZZOLE EDİLEN MAYALARIN ENZİMATİK KARAKTERİZASYONU}

\section{ÖZ}

$\mathrm{Bu}$ çalışmada, Van otlu peyniri üretiminde kullanılan fermente salamura otlarından mayaların izolasyonu, identifikasyonu ve enzimatik aktivitelerinin belirlenmesi amaçlanmıştır. Yirmi adet maya izolatı izole edilerek moleküler olarak tanımlanmıştır. Tanımlamada 26S rRNA gen bölgesinin D1/D2 alt bölgesi çoğaltılarak sekanslanmıştır. Sekanslama sonucunda Picbia membranifaciens $(n=8)$, Kazachstania servazzii $(n=6)$, Debaryomyces hansenii $(n=2)$, Kluyveromyces marxianus $(n=2)$ ve Pichia

\footnotetext{
* This paper includes data from MSc thesis of Erkan Güneş. A part of this study was presented as a poster at the $2^{\text {nd }}$ International Congress on Food Technology, November 05-07, 2014, Kuşadası, Aydın Turkey and published as an abstract in Congress Abstract Book. / Bu çalışma Erkan Güneş'in yüksek lisans tez çalışmasından veriler içermektedir. Bu çalışmanın bir kısmı 2. Uluslararası Gıda Teknolojisi Kongresi, 05-07 Kasım 2014, Kuşadası, Aydın, Türkiye'de poster olarak sunulmuş ve kongre kitabında özeti bildiri olarak basılmıştır.
}

${ }^{* *}$ Corresponding author / Yazışmalardan sorumlu yazar:

凶: ibrahimcakir@ibu.edu.tr

(2) (+90) 374254 1000/4827

暍: (+90) 3742534558

Erkan Güneş; ORCID no: 0000-0001-8666-9124

Furkan Aydın; ORCID no: 0000-0003-2924-5434

İbrahim Çakır; ORCID no: 0000-0001-7775-1871 
fermentans $(n=2)$ türleri tanımlanmıştır. İzolatların enzim profilleri API-ZYM test kitleri kullanılarak belirlenmiştir. İzolatların, peynirin olgunlaşması sırasında önemli rollere sahip olabilecek alkali ve asit fosfataz, esteraz, esteraz lipaz, aminopeptidazlar ve proteazlar dahil olmak üzere çeşitli enzim aktivitelerine sahip olduğu belirlenmiştir. İzolatlar arasından, K. marxianus M8.1, D. hansenii M6.1 ile M6.1, P. membraniciens M13.1, M13.2 ile M14.1 suşlarının üstün enzimatik özellikler taşıdığ1 görülmüştür. Bu tür enzimatik faaliyetlerin, Van otlu peyniri üretimi için starter laktik asit bakterileri ile birlikte ek kültürün belirlenmesi için teknolojik bir öneme sahip olabileceği düşünülmektedir.

Anahtar kelimeler: Salamura çözeltisi, ot, maya, enzim aktivitesi.

\section{INTRODUCTION}

Yeast constitute the microflora of many artisanal cheeses (Frohlich-Wyder et al., 2019). Sources of yeast in cheese are quite complex due to their ability to tolerate extreme conditions such as low $\mathrm{pH}$ and reduced water activity with enhancing brine concentrations. They are widely dispersed in a cheese-making environment, raw milk, and on the surfaces of cheese-making tools (Banjara et al., 2015). The herbs and spontaneously fermented herbs are also great contamination sources of different yeast species as well as lactic acid bacteria (LAB) (Cakir, 2010). They play crucial roles in the production of nearly all types of artisanal cheeses (Haastrup et al., 2018). The initially abundant yeast species in cheese are reported to be salt-tolerant. They have the ability to metabolize lactate produced by LAB in the early stage of ripening as well as producing $\mathrm{NH}_{3}$ from amino acids, thus increasing the $\mathrm{pH}$ of the cheese. The deacidification process gives rise to bacteria, mainly non-starter LAB, to grow and pursues the ripening (Frohlich-Wyder et al., 2019). Moreover, thanks to their lipolytic, proteolytic, and extensive extracellular enzymatic activity, they have substantial effects on the development of cheese flavor and texture (McSweeney, 2004). The contribution of yeast to cheese technology has enabled them to be included in adjunct culture studies for the recent years (Atanassova et al., 2016; Binetti et al., 2013; De Freitas et al., 2008; Kesenkas and Akbulut, 2008).

Herby (Otlu) cheese is a semi-hard and herbflavored artisanal cheese manufactured mainly from raw sheep's milk in the eastern part of Turkey for over 200 years (Tarakci et al., 2004). Approximately 25 different herbs are used alone or as mixtures of a few prepared in brine, among which Allium, Thymus, Anthriscus, and Ferula are the most commonly used at levels of $0.5-2.0 \mathrm{~kg}$ per $100 \mathrm{~kg}$ milk (Coskun, 1998; Hayaloglu and Farkye, 2011). It still continues to gain popularity among consumers demanding robust flavors due to its unique garlic and thyme aroma distinguishing Van herby cheese from other artisanal cheeses in aroma perspective. Although the chemistry and biochemistry of Van herby cheese have been very-well studied, the microbiological aspect regarding the isolation and characterization of yeast remains unclear.

There has been a growing interest in studying yeast isolated from traditional cheeses in recent years, which mainly focus on genetic characterization, determining their roles in ripening and evaluating their technological and probiotic characteristics more in particular (Aydin et al., 2020; Binetti et al., 2013). Four significant yeast species, which are Yarrowia lipolytica, Kluyveromyces marxianus, K. lactis, and Debaryomyces hansenii, were reported to be the most isolated species from artisanal cheeses and their brine solutions and are described in more detail (Atanassova et al., 2016; Banjara et al., 2015; Ceugniez et al., 2015). On the other hand, Pichia membranifaciens, $P$. fermentans, $P$. kudriavzevii, Galatactomyces candidum, Saccharomyces cerevisiae, and some species belonging to Candida genus were isolated in lesser amounts (Aponte et al., 2010; Zheng et al., 2018). Taking into account that yeast plays essential roles during ripening as well as $\mathrm{LAB}$, there is still a need for determining endogenous yeast microflora of artisanal cheeses and their technological properties extensively. Some studies regarding technological characteristics of yeast isolated from different artisanal cheeses, including Erzincan Tulum cheese, Mihalic cheese, Fossa cheese, and Serpa cheese, were carried out (Biagiotti et al., 2018; 
Dos Santos et al., 2017; Karasu-Yalcin et al., 2012: 2017). Yet, to the best of our knowledge, yeast from Herby cheese or spontaneously fermented herb solutions has not been studied in detail. This study aims to identify yeast from naturally fermented herb brines used for the production of Herby cheese and evaluate their enzymatic characteristics.

\section{MATERIALS AND METHODS}

\section{Fermented brine solutions}

Fermented herb brine solutions containing Allium schoenoprasum, Anthriscus nemorosa, Prangos ferulacea, and Chaerophyllum macropodum alone and as a mixture of a few were provided by Professor Yusuf Tuncturk from Food Engineering Department of Van Yuzuncu Yil University (Van, Turkey). The detailed information regarding the isolation materials is given in Table 1 within the result and discussion section.

\section{Isolation of yeasts}

Twenty-five grams of herb brine solutions were taken and homogenized in $225 \mathrm{~mL}$ of sterile saline solution $(0.85 \% \quad \mathrm{NaCl})$ using a stomacher (MAYO, HG-400, Australia). Series of dilutions up to $10^{-5}$ were prepared. Duplicate aliquots (100 $\mu \mathrm{L}$ ) of appropriate dilutions were inoculated onto Potato Dextrose Agar (Oxoid, UK) pH 5.0 supplemented with $100 \mathrm{mg} / \mathrm{kg}$ of chloramphenicol (Sigma Aldrich, USA). The plates were incubated at $28^{\circ} \mathrm{C}$ for $3-5$ days. Morphologically different colonies were selected and isolated by streaking plate technique to obtain pure cultures for molecular identification. Isolates were maintained in YPD broth (Sigma Aldrich, USA) with (v/v) $20 \%$ added glycerol and as slant in the same medium supplemented with $1.5 \%$ agar (Sigma Aldrich, USA) without glycerol.

\section{Molecular identification of isolates}

DNA of each strain was extracted using a commercial product of DNeasy Blood and Tissue kit (Qiagen, Cat No./ID: 69504) according to the manufacturer's instructions. The final quantity of DNA was evaluated by the DS-11 FX+ spectrophotometer (Denovix, USA) and diluted to $50 \mathrm{ng}$ using sterile ultra-pure water. Template DNA samples were stored at $-20^{\circ} \mathrm{C}$ till used.
For amplification of the D1/D2 domain of the $26 \mathrm{~S}$ rRNA gene of the isolates, NL1 (5'-GCA TAT CAA TAA GCG GAG GAA AAG-3') and NL4 (5'-TCC TCC GTC TAT TGA TAT GC-3') primer pairs were employed (Kurtzman and Robnett, 1998). PCR reactions were performed in a $50 \mu \mathrm{L}$ reaction mixture containing $1 \times$ PCR reaction buffer, $200 \mu \mathrm{m}$ dNTPs, $0.4 \mu \mathrm{M}$ each primer, 1.5-unit Taq DNA Polymerase (New England BioLabs, MA), and 50 ng template DNA. The PCR amplification was carried out in a T100 thermal cycler (Bio-Rad, Hercules, CA, USA). It included 3 min of initial denaturation step at $94^{\circ} \mathrm{C}$, followed by 35 cycles with $35 \mathrm{~s}$ denaturation at $94^{\circ} \mathrm{C}, 40 \mathrm{~s}$ annealing at $55^{\circ} \mathrm{C}$, and $1 \mathrm{~min}$ extension at $72^{\circ} \mathrm{C}$ with $10 \mathrm{~min}$ of final extension at $72^{\circ} \mathrm{C}$. Amplification products were visualized on an agarose gel to check the amplification. The amplicons were subjected to bidirectional sequencing in a commercial company (Macrogen Inc., Seoul, Korea).

The sequence data were subjected to the BLAST search in the GenBank database (http://blast.ncbi.nlm.nih.gov/) to match with the closest available reference sequences in the complete National Center for Biotechnology Information (NCBI) nucleotide collection. Accordingly, the accession numbers for the D1/D2 domain of the isolates submitted to NCBI are MT040771 through MT040790. Phylogenetic and molecular evolutionary analyses of 20 isolates from this study and corresponding yeast isolates deposited in the nucleotide database of GenBank (P. membranifaciens: DQ409149; KY108894; K. servazzii: MH704181; D. hansenii: KY107508; K. marxianus KT945093; P. fermentans KY108803) were aligned with CLUSTAL W (Thompson et al., 1994). Sequences were edited manually using MEGAX (Kumar et al., 2018) for higher accuracy, which is given in detail by Ozer and Bayraktar (2018). A neighbor-joining tree was constructed using Tamura and Nei (1993) model with bootstrap analyses using the heuristic search option conducted with 1,000 replicates.

\section{Growth at different salt concentrations}

The yeast strains were grown in $10 \mathrm{~mL}$ of YPD broth (Sigma Aldrich, USA) in the 
presence of different $\mathrm{NaCl}$ concentrations $(7.5 \%$, $10 \%$, and $12.5 \%$ ) for two weeks at $28^{\circ} \mathrm{C}$.

\section{Enzymatic characterization}

Enzymatic activity of yeast was determined using the API-ZYM test system (BioMérieux, France) thanks to which 19 different enzyme activity can be rapidly analyzed. Previously activated yeast cultures were grown on PDA by streaking plate technique. After the incubation period, single colonies were taken and suspended in distilled water till they reach 5-6 McFarland turbidity. Then the $65 \mu \mathrm{L}$ of suspensions were inoculated to the wells of API-ZYM strip and incubated at $37^{\circ} \mathrm{C}$ for around 4-5 hours before the addition of ZYM $A$ and $Z Y M B$ reagents to each cupule. The color formation was awaited for around 5 minutes. The strips were held under a $1000 \mathrm{~W}$ lamp for 10 seconds to prevent the formation of yellow color due to Fast Blue BB. Enzyme activity was graded from 0 to 5 by comparison of color formed within 5 minutes to the API-ZYM color reaction chart, and the results were expressed on a scale from 0 (no activity) to 5 (maximum activity).
RESULTS AND DISCUSSION

Identification of the strains and phylogenetic analyses

A total of 20 yeast isolates obtained from naturally fermented herbs used for the production of Herby cheese were identified by sequencing the D1/D2 domain of 26S rRNA. Among all, eight were ascribed to Pichia membranifaciens (40.0\%), 6 to Kazachstania servazzii (30.0\%), 2 to Debaryomyces bansenii (\%10) 2 to Kluyveromyces marxianus (\%10) and 2 to Picbia fermentans (\%10), respectively. The isolates were confirmed by the BLASTn algorithm running on the NCBI website for each strain. The fragments amplified using NL1 and NL4 primers ranged from 552 to 651 bp long, with identity matches of $99-100 \%$ with corresponding species from the GenBank. All sequences belonging D1/D2 domain of 26S rRNA obtained in this study have been submitted to the GenBank database with the accession numbers, as indicated in Table 1 with detail information.

Table 1. The detailed information regarding yeasts.

\begin{tabular}{|c|c|c|c|}
\hline Strain & Source & Identified species & Accession $\mathrm{N}^{\circ}$ \\
\hline M10.1 & Anthriscus nemorosa in brine & Pichia membranifaciens & MT040779 \\
\hline M11.1 & Allium schoenoprasum + Anthriscus nemorosa in brine & Pichia membranifaciens & MT040780 \\
\hline M13.1 & $\begin{array}{l}\text { Anthriscus nemorosa }+ \text { Allium schoenoprasum }+ \\
\text { Chaerophyllum macropodum in whey brine }\end{array}$ & Pichia membranifaciens & MT040782 \\
\hline M13.2 & $\begin{array}{l}\text { Anthriscus nemorosa }+ \text { Allium schoenoprasum }+ \\
\text { Chaerophyllum macropodum in whey brine }\end{array}$ & Pichia membranifaciens & MT040783 \\
\hline M14.1 & Prangos ferulacea in brine & Pichia membranifaciens & MT040784 \\
\hline M15.2 & Allium schoenoprasum in whey brine & Pichia membranifaciens & MT040786 \\
\hline M17.1 & Chaerophyllum macropodum in whey brine & Pichia membranifaciens & MT040787 \\
\hline M18.2 & Allium schoenoprasum in whey brine & Pichia membranifaciens & MT040790 \\
\hline M5.1 & Allium schoenoprasum in whey brine & Kazachstania servazzii & MT040771 \\
\hline M5.2 & Allium schoenoprasum in whey brine & Kazachstania servazzii & MT040772 \\
\hline M6.4 & Anthriscus nemorosa in whey brine & Kazachstania servazzii & MT040775 \\
\hline M9.1 & Allium schoenoprasum in whey brine & Kazachstania servazzii & MT040778 \\
\hline M11.2 & Allium schoenoprasum + Anthriscus nemorosa in brine & Kazachstania servazzii & MT040781 \\
\hline M15.1 & Allium schoenoprasum in whey brine & Kazachstania servaz:ii & MT040785 \\
\hline M6.1 & Anthriscus nemorosa in whey brine & Debaryomyces hansenii & MT040773 \\
\hline M6.3 & Anthriscus nemorosa in whey brine & Debaryomyces hansenii & MT040774 \\
\hline M8.1 & Prangos ferulacea in whey brine & Kluyveromyces marxianus & MT040776 \\
\hline M17.3 & Chaerophyllum macropodum in whey brine & Kluyveromyces marxianus & MT040789 \\
\hline M8.2 & Prangos ferulacea in whey brine & Pichia fermentans & MT040777 \\
\hline M17.2 & Chaerophyllum macropodum in whey brine & Pichia fermentans & MT040788 \\
\hline
\end{tabular}


P. membranifaciens strains were found to be the dominant species along with K. servazzii, which is a basionym of Saccharomyces servazzii. The prevalence of yeast species differs according to the type of cheese, its origin, raw materials used, and ripening conditions. Most of the researchers reveals that $D$. hansenii was mostly isolated yeast species among traditionally produced raw milk cheeses, especially those manufactured from raw ewes' or goats' milk. As, it can grow in high salt concentrations (Aponte et al., 2010; KarasuYalcin et al., 2017; Padilla et al., 2014). Similar to our results, Mei et al. (2014) found that K. servazzii was the dominant species along with $S$. cerevisiae in a Camembert-type cheese type by cultureindependent PCR-denaturating gel electrophoresis (PCR-DGGE). However, Lavoie et al. (2012) reported that K. servazzii could be found in non-dominant microflora of milk and cheese along with P. membranifaciens. K. servazzii were mostly isolated from alcoholic beverages (Moon et al., 2014; Spitaels et al., 2014) and sourdough (Lhomme et al., 2015). It is noteworthy that, the presence of $K$. servazzii in naturally fermented herbs could be attributed to the assimilation of lactic acid produced by LAB present in the brine. K. marxianus is frequently isolated from whey, brine, and different type of cheeses due to its ability to ferment lactose (Cardoso et al., 2015; Haastrup et al., 2018; Lane and Morissey, 2010). Apart from D. hansenii and $K$. marxianus, many researchers also reported Yarrowia lipolytica, and Galactomyces candidum species to have been isolated from different kinds of artisanal cheeses as a result of molecular identification (Ceugniez et al., 2017; Dugat-Bony et al., 2016). Similar to our results, Álvarez-Martín et al. (2007) reported that P. fermentans strains constituted the non-dominant microflora of Spanish blue-veined Cabrales cheese.

In some of the other studies in which molecular techniques were not applied for identification, some species belonging to Candida genus and Cryptococcus laurenti were reported (Al-Otaibi 2012; Karasu-Yalcin et al., 2017). Even in some cases, identification using molecular methods in which Internally Transcript Sequence (ITS) region is amplified by PCR makes some challenges to differentiate between species. Partial amplification of large subunit is often of choice (Aydin et al., 2020). Nnon-molecular techniques may not give the best results owing to the inherent phenotypic and genetic heterogeneity in populations, or the limited ability of phenotypic tests used to identify species.

Phylogenetic analysis based upon the D1/D2 domain of $26 \mathrm{~S}$ rRNA sequences of isolates was carried out employing the neighbor-joining analyses with 1,000 replicates revealing polymorphism between species (Figure 1). The percentage of replicate trees where the associated taxa clustered together in the bootstrap test is indicated adjacent to the branches. The phylogenetic tree divided all isolates into two major groups, which are shown in Figure 1 as Cluster-I and Cluster-II. In the first cluster, there are two sub-clusters formed with high bootstrap values within the genus of Pichia. The second cluster, however, was divided into three subclusters between D. hansenii, $K$. marxianus, and $K$. servazzizi species.

\section{Growth abilities at differen $\mathrm{NaCl}$ concentrations}

All isolates were able to grow in the presence of salt with concentrations of 7.5 and $10 \%$, apart from $P$. fermentans strains. Only three strains of $P$. membranifaciens (M13.1, M13.2, M14.1) and both of $D$. hansenii were able to grow at $12.5 \% \mathrm{NaCl}$ concentration. Taking into account that salt content can reach up to $9.07 \%$ in Van herby cheese (Tarakci et al., 2004), all of the strains, except for P. fermentans M8.2 and M17.2, could be present in ripened Van herby cheese, which has high salt concentrations particularly, according to population dynamics.

\section{Enzymatic activities}

Enzyme profiles of the strains are given in detail in Table 2 and Figure 2. Nearly most of the isolates exhibited very low $\alpha$-glucosidase, $\beta$ glucosidase, $\alpha$-mannosidase, and $\alpha$-fucosidase activities while none of the isolates showed $\beta$ glucuronidase and $\mathrm{N}$-acetyl- $\beta$-glucosaminidase activities. Kluyveromyces marxianus M8.1, D. hansenii M6.1, and M6.3 had vigorous $\beta$-glucosidase 
activity, which is a crucial enzyme for the conversion of galactose into glucose-6-phosphate using Leloir pathway with lactose permease. The high $\beta$-glucosidase activity among $K$. marxianus and $D$. hansenii strains were reported in yeast isolated from feta cheese (Psomas et al., 2001).
Since the presence or availability of either lactose or galactose in cheese is generally limited, these strains may be essential for residual lactose metabolism during ripening of the herby cheese (Frohlich-Wyder et al., 2019).

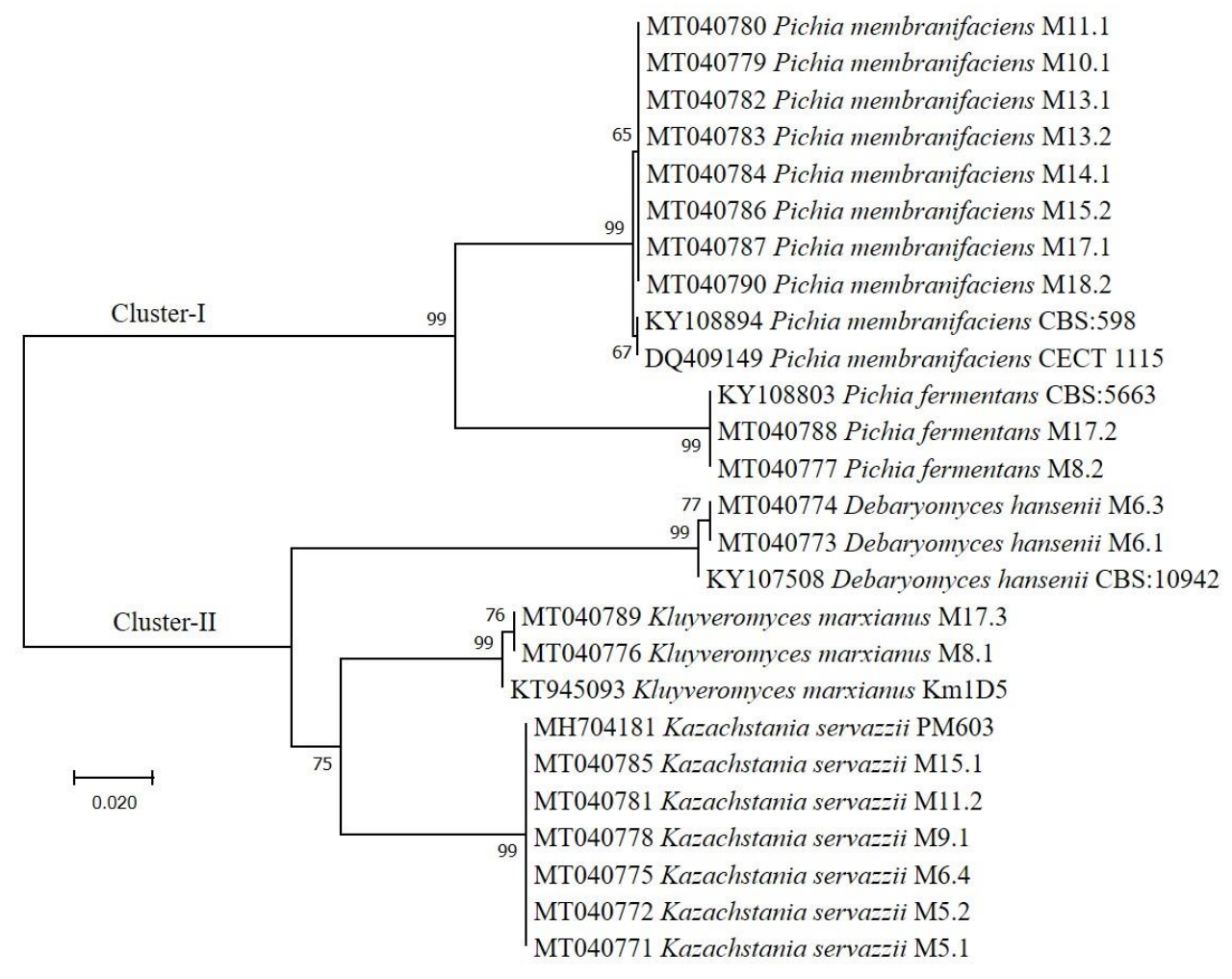

Figure 1. Phylogenetic tree of yeasts generated by neighbor-joining analysis with bootstrap of 1,000.

All isolates had proteolytic enzyme activities of arylamidases (aminopeptidases) which catalyze the hydrolysis of $\mathrm{N}$-terminal amino acids from peptide, amide, and arylamides (Dodor and Tabatabai, 2007). These enzymes were reported to prevent the bitter taste that occurred during the ripening in mold-ripened soft cheeses since they are essential tools in the liberation of amino acids and the development of the desired flavor (Gobbetti et al., 2015). Besides, some of aldehyde and alcohol derivatives are usually formed from the degradation of valine, methionine, leucine, and methionine (Zeng et al., 2014). High leucine arylamidase activities were also reported in Erzincan Tulum cheese and Mihalic cheese by
Karasu-Yalcin et al. (2012, 2017). Our results reveal high valine and cystine arylamidase activities which differs from the isolates obtained from Tulum and Mihalic cheeses. According to the results reported by Kesenkas and Akbulut (2006), K. marxianus and D. hansenii were found to stimulate the growth of Lactococcus lactis subsp. lactis and Lactococcus lactis subsp. cremoris in the early stage of the ripening period, where yeasts were used as adjunct cultures, probably by liberating of peptides. Eventhough most of the production of Van herby cheese is made from raw milk in households, the controlled production includes pasteurazation and starter culture addition, in which $L$. lactis subsp. lactis and $L$. lactis subsp. 
cremoris cultures are used (Ocak et al., 2015). K. marxianus M8.1, D. hansenii M6.1 and M6.3 strains may have a special role in stimulating the growth of these two starters during the early stages of ripening.

Table 2. Enzyme activity assay obtained by API-ZYM kit.

\begin{tabular}{|c|c|c|c|c|c|c|c|c|c|c|c|c|c|c|c|c|c|c|c|c|}
\hline Isolate & Control & 1 & 2 & 3 & 4 & 5 & 6 & 7 & 8 & 9 & 10 & 11 & 12 & 13 & 14 & 15 & 16 & 17 & 18 & 19 \\
\hline Pm 10.1 & 0 & 4 & 5 & 3 & 0 & 5 & 4 & 4 & 0 & 0 & 5 & 5 & 0 & 0 & 0 & 0 & 0 & 0 & 0 & 0 \\
\hline Pm 11.1 & 0 & 4 & 4 & 3 & 1 & 5 & 4 & 4 & 1 & 1 & 5 & 5 & 1 & 1 & 0 & 0 & 0 & 0 & 1 & 0 \\
\hline Pm 13.1 & 0 & 4 & 5 & 3 & 1 & 5 & 4 & 3 & 1 & 1 & 5 & 5 & 1 & 1 & 0 & 0 & 0 & 0 & 0 & 0 \\
\hline Pm 13.2 & 0 & 2 & 4 & 3 & 1 & 5 & 3 & 3 & 1 & 1 & 5 & 5 & 0 & 1 & 0 & 1 & 1 & 0 & 1 & 1 \\
\hline Pm 14.1 & 0 & 1 & 4 & 3 & 0 & 5 & 4 & 4 & 0 & 0 & 5 & 5 & 0 & 0 & 0 & 0 & 0 & 0 & 0 & 0 \\
\hline Pm 15.2 & 0 & 3 & 5 & 3 & 2 & 5 & 4 & 4 & 0 & 0 & 5 & 5 & 0 & 0 & 0 & 0 & 0 & 0 & 0 & 0 \\
\hline Pm 17.1 & 0 & 3 & 5 & 3 & 1 & 4 & 5 & 5 & 1 & 1 & 5 & 5 & 1 & 1 & 0 & 0 & 0 & 0 & 0 & 0 \\
\hline Pm 18.2 & 0 & 5 & 4 & 2 & 1 & 5 & 4 & 4 & 0 & 0 & 5 & 5 & 0 & 0 & 0 & 0 & 0 & 0 & 0 & 0 \\
\hline Ks 5.1 & 0 & 2 & 5 & 4 & 1 & 5 & 3 & 3 & 1 & 1 & 0 & 3 & 0 & 0 & 0 & 0 & 0 & 0 & 1 & 0 \\
\hline Ks 5.2 & 0 & 1 & 5 & 4 & 1 & 5 & 3 & 3 & 1 & 1 & 2 & 3 & 0 & 0 & 0 & 0 & 0 & 0 & 0 & 1 \\
\hline Ks 6.4 & 0 & 1 & 5 & 3 & 1 & 5 & 3 & 3 & 1 & 1 & 1 & 3 & 2 & 1 & 0 & 0 & 0 & 0 & 1 & 0 \\
\hline Ks 9.1 & 0 & 1 & 4 & 3 & 1 & 5 & 3 & 3 & 1 & 1 & 1 & 3 & 2 & 1 & 0 & 0 & 0 & 0 & 0 & 0 \\
\hline Ks 11.2 & 0 & 1 & 5 & 3 & 1 & 5 & 3 & 3 & 1 & 1 & 2 & 3 & 0 & 0 & 0 & 1 & 0 & 0 & 1 & 0 \\
\hline Ks 15.1 & 0 & 0 & 5 & 4 & 0 & 5 & 4 & 4 & 0 & 0 & 2 & 2 & 0 & 0 & 0 & 0 & 0 & 0 & 0 & 0 \\
\hline Dh 6.1 & 0 & 4 & 5 & 3 & 0 & 5 & 2 & 3 & 0 & 0 & 4 & 2 & 0 & 4 & 0 & 1 & 0 & 0 & 0 & 0 \\
\hline Dh 6.3 & 0 & 5 & 4 & 3 & 1 & 5 & 3 & 2 & 0 & 0 & 5 & 2 & 0 & 4 & 0 & 0 & 0 & 0 & 0 & 0 \\
\hline $\mathrm{Km} 8.1$ & 0 & 5 & 4 & 3 & 1 & 5 & 4 & 3 & 1 & 1 & 5 & 4 & 1 & 5 & 0 & 1 & 4 & 0 & 1 & 1 \\
\hline Km17.3 & 0 & 1 & 4 & 3 & 0 & 5 & 5 & 5 & 0 & 0 & 5 & 5 & 0 & 0 & 0 & 0 & 0 & 0 & 0 & 0 \\
\hline Pf M8.2 & 0 & 1 & 4 & 3 & 0 & 5 & 4 & 3 & 0 & 0 & 5 & 5 & 0 & 0 & 0 & 0 & 0 & 0 & 0 & 0 \\
\hline Pf 17.2 & 0 & 2 & 4 & 3 & 0 & 5 & 4 & 4 & 0 & 0 & 5 & 5 & 0 & 0 & 0 & 0 & 0 & 0 & 0 & 0 \\
\hline
\end{tabular}

Pm: Pichia membranifaciens, Ks: Kazachstania servaz:iii, Dh: Debaryomyces hansenii, Km: Khyveromyces marxianus, Pf: Picbia fermentans 1: Alkaline phosphatase, 2: Esterase (C4), 3: Esterase lipase (C8), 4: Lipase (C14) 5: Leucine arylamidase, 6: Valine arylamidase, 7: Cystine arylamidase, 8: Trypsin, 9: $\alpha$-chymotrypsin, 10: Acid phosphatase, 11: NaphtolAS-BI-phosphohydrolise, 12: $\alpha$-galactosidase, 13: $\beta$-galactosidase, 14: $\beta$-glucuronidase, 15: $\alpha$-glucosidase, 16 : $\beta$ glucosidase, 17: $\mathrm{N}$-acetyl- $\beta$-glucoaminidase, 18: $\alpha$-mannosidase, 19: $\alpha$-fucosidase.

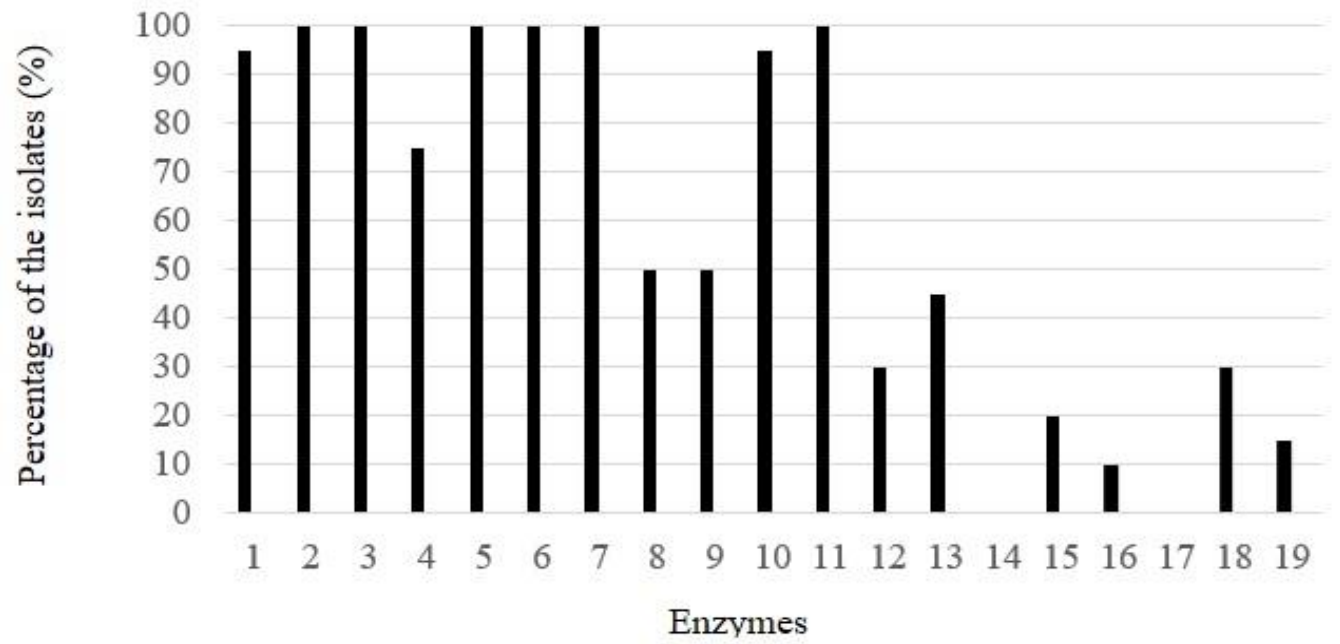

Figure 2. Percentage of yeast isolates having 19 different enzyme activities.

1: Alkaline phosphatase, 2: Esterase (C4), 3: Esterase lipase (C8), 4: Lipase (C14) 5: Leucine arylamidase, 6: Valine arylamidase, 7: Cystine arylamidase, 8: Trypsin, 9: $\alpha$-chymotrypsin, 10: Acid phosphatase, 11: Naphtol-AS-BIphosphohydrolise, 12: $\alpha$-galactosidase, 13: $\beta$-galactosidase, 14: $\beta$-glucuronidase, 15: $\alpha$-glucosidase, 16 : $\beta$ glucosidase, 17: $\mathrm{N}$-acetyl- $\beta$-glucoaminidase, 18: $\alpha$-mannosidase, 19: $\alpha$-fucosidase 
Either weak or no trypsin and $\alpha$-chymotrypsin activities were observed. Strains displaying low proteinase and relatively strong peptidase activities are essential for the cheese technology. They improve the texture defects in the cheese and have debittering effects (Mathara et al., 2004). Such isolates could have a technological importance for the production of Van herby cheese. According to alkaline and acid phosphatase results, most of the strains exhibited higher acid phosphatase activities. The reason for this is thought to arise from the fact that acid phosphatase has higher thermal activity as well as having lower optimum working $\mathrm{pH}$ (Stepaniak, 2004). It acts synergistically with proteolytic enzymes and hydrolyzes casein molecules. This synergetic action gives rise to the extensive production of small peptides and free amino acids. It contributes significantly to the cheese ripening in the point of view of aroma production (Akuzawa and Fox, 2004). On the other hand, all isolates displayed esterase (C4) and esterase lipase (C8) activities, while lipase (C14) activity was observed very weekly for most of the isolates. Lipases are carboxylesterases which catalyze the hydrolysis of the ester linkages on lipids; thus, it results in the liberation of free fatty acids (Decimo et al., 2017). Many researchers have reported different amount of lipolytic strains even for the same species (Karasu-Yalcin et al., 2017; Landel et al., 2006). This discrepancy is thought to arise not only from the strains difference but also from the difference in the application methods. It is hard to evaluate lipolytic activities on an agar medium in which tributyrin and Tween 20 is often used for lipase production. Since lipolysis affects the aroma dramatically, strains displaying moderate or high lipase, esterase, and lipase esterase activities have the potential to be used as adjunct starter cultures.

All strains were evaluated to have multiple and diverse enzymatic activities. Although low protease activity is the case for most of the adjunct culture to prevent the bitter taste, acid phosphatase and arylamidase have crucial roles during the ripening period. Taking into account these parameters, P. membranifaciens M13.1, M13.2, and M14.1 had strong acid phosphate and arylamidase activities as well as growing well under high salt concentrations. In addition to high acid phosphatase and arylamidase activities, $\beta$ galactosidase activitiy should also be taken into account for the conversion of galactose to glucose-6-phosphate. Accordingly, K. marxianus M8.1, D. hansenii M6.1 and M6.3 were found to have B-galactosidase activity with high acid phosphatase and moderate arylamydase activities.

\section{CONCLUSIONS}

Yeast microflora of spontaneously fermented herbs used for the production of Van herby cheese was identified and enzymatic characterization of the isolates was evaluated as a tool for technological characterization. It has been revealed that fermented herb brines included the species of $P$. membranifaciens, $K$. servazzii, D. hansenii, K. marxianus, and P. fermentans, as a result of partial large subunit sequencing. The isolates were found to have variable enzyme activities including, phospahatase, $\beta$ galactosidase, lipases, esterase, arylamydases, which could be crucial during the ripening of Van herby cheese. Selected strains can be used in adjunct culture combines for herby cheese production, however, to this end, more studies are required in a proper herby cheese food matrix.

\section{ACKNOWLEDGEMENTS}

The authors would like to thank Prof. Dr. Hayri Coşkun and Prof. Dr. Yusuf Tunçtürk for supplying natural herbs from Van province of Turkey.

\section{CONFLICT OF INTEREST}

The author(s) declares no potential conflicts of interest with respect to the research, authorship, and/or publication of this article.

\section{AUTHORS CONTRIBUTIONS}

Erkan Güneş and İbrahim Çakır performed isolation and enzymatic assay of the isolates. Furkan Aydin made the molecular analyses and wrote the manuscript. All authors read and approved the final manuscript. 


\section{REFERENCES}

Akuzawa, R., P.F. Fox. (2004). Acid phosphatase in cheese. Anim. Sci. 75 (5): 385-391, doi: 10.1111/j.1740-0929.2004.00202.x

Al-Otaibi, M.M. (2012). Isolation and identification of lactic acid bacteria and yeasts from Sameel milk: a Saudi traditional fermented milk. Int. J. Dairy Sci. 7: 73-83, doi: 10.3923/ijds.2012.73.83

Álvarez-Martín, P., Flórez, A.B., López-Díaz, T.M., Mayo, B. (2007). Phenotypic and molecular identification of yeast species associated with Spanish blue-veined Cabrales cheese. Int. Dairy J. 17 (8): 961-967, doi: 10.1016/j.idairyj.2006.11.005

Aponte, M., Pepe, O., Blaiotta, G. (2010). Identification and technological characterization of yeast strains isolated from samples of water buffalo Mozzarella cheese. J. Dairy Sci. 93(6): 2358-2361, doi: 10.3168/jds.2009-2948

Atanassova, M.R., Fernández-Otero, C., Rodríguez-Alonso, P., Fernández-No, I.C., Garabal, J. I., J., Centeno, A. (2016). Characterization of yeasts isolated from artisanal short-ripened cows' cheeses produced in Galicia (NW Spain). Food Microbiol. 53: 172-181, doi: 10.3168/jds.2009-2948

Aydin, F., Ozer, G., Alkan, M., Cakir, I. (2020). The utility of iPBS retrotransposons markers to analyze genetic variation in yeast. Int. J. Food Microbiol. $\quad 325 \mathrm{C}$ : 108647, doi: 10.1016/j.ijfoodmicro.2020.108647

Banjara, N., Suhr, M.J., Hallen-Adams, H.E. (2015). Diversity of yeast and mold species from a variety of cheese types. Curr. Microbiol. 70(6): 792-800, doi: 10.1007/s00284-015-0790-1

Biagiotti, C., Ciani, M., Canonico, L., Comitini, F. (2018). Occurrence and involvement of yeast biota in ripening of Italian Fossa cheese. Eur. Food Res. Technol. 244 (11): 1921-1931, doi: 10.1007/s00217-018-3104-6

Binetti, A., Carrasco, M., Reinheimer, J., Suárez, V. (2013). Yeasts from autochthonal cheese starters: technological and functional properties. J. Appl. Microbiol. 115(2): 434-444, doi: $10.1111 /$ jam. 12228
Gobbetti, M., De Angelis, M., Di Cagno, R., Mancini, L., Fox, P.F. (2015). Pros and cons for using non-starter lactic acid bacteria (NSLAB) as secondary/adjunct starters for cheese ripening. Trends Food Sci. Technol. 45(2): 167-178, doi: 10.1016/j.tifs.2015.07.016

Cakir I. (2010). Antibacterial and antifungal activities of some lactic acid bacteria isolated from naturally fermented herbs. J Food Agric. Environ. 8: 223-226.

Cardoso, V.M., Borelli, B.M., Lara, C. A., Soares, M.A., Pataro, C., Bodevan, E.C., Rosa, C.A. (2015). The influence of seasons and ripening time on yeast communities of a traditional Brazilian cheese. Food Res. Int. 69: 331-340, doi: 10.1016/j.foodres.2014.12.040

Ceugniez, A., Drider, D., Jacques, P., Coucheney, F. (2015). Yeast diversity in a traditional French cheese "Tomme d'orchies" reveals infrequent and frequent species with associated benefits. Food Microbiol. $\quad 52$ : 177-184, doi: 10.1016/j.fm.2015.08.001

Ceugniez, A., Taminiau, B., Coucheney, F., Jacques, P., Delcenserie, V., Daube, G., Drider. D. (2017). Fungal diversity of "Tomme d'Orchies" cheese during the ripening process as revealed by a metagenomic study. Int. J. Food Microbiol. 258: 89-93, doi: 10.1016/j.ijfoodmicro.2017.07.015

Coskun, H. (1998). Microbiological and biochemical changes in herby cheese during ripening. Nahrung. 42(5): 309-313, doi: http://dx.doi.org/10.1002/(SICI)1521-

3803(199810)42:05\%3C309::AID-

FOOD309\%3E3.0.CO;2-U

De Freitas, I., Pinon, N., Berdagué, J. L., Tournayre, P., Lortal, S., Thierry, A. (2008). Kluyveromyces lactis but not Pichia fermentans used as adjunct culture modifies the olfactory profiles of Cantalet cheese. J. Dairy Sci. 91(2): 531-543, doi: 10.3168/jds.2007-0136.

Decimo, M., Brasca, M., Ordóñez, J.A., Cabeza, M.C. (2017). Fatty acids released from cream by psychrotrophs isolated from bovine raw milk. Int. J. Dairy Technol. 70 (3): 339-344, doi: 10.1111/1471-0307.12347 
Dodor, D.E., Tabatabai, M.A. (2007). Arylamidase activity as an index of nitrogen mineralization in soils. Commun. Soil Sci. Plan. 38 (15-16): 2197-2207, doi: 10.1080/00103620701549132

Dos Santos, M.T.P.G., Benito, M. J., de Guía Córdoba, M., Alvarenga, N. And Herrera, S.R. M.S. (2017). Yeast community in traditional Portuguese Serpa cheese by culture-dependent and-independent DNA approaches. Int. J. Food Microbiol. 262: 63-70, doi: 10.1016/j.ijfoodmicro.2017.09.013

Dugat-Bony, E., Garnier, L., Denonfoux, J., Ferreira, S., Sarthou, A.S., Bonnarme P., Irlinger, F. 2016. Highlighting the microbial diversity of 12 French cheese varieties. Int. J. Food Microbiol, 238: 265-273, doi: 10.1016/j.ijfoodmicro.2016.09.026

Frohlich-Wyder, M.T., Arias-Roth, E., E. Jakob. (2019). Cheese yeasts. Yeast. 36 (3): 129-141, doi: 10.1002/yea.3368

Haastrup, M. K., Johansen, P., Malskær, A. H., Castro-Mejía, J. L., Kot, W., Krych, Arneborg, N., Jespersen, L. (2018). Cheese brines from Danish dairies reveal a complex microbiota comprising several halotolerant bacteria and yeasts. Int. J. Food Microbiol. 285: 173-187, doi: 10.1016/j.ijfoodmicro.2018.08.015

Hayaloglu, A.A., N. Y. Farkye. 2011. Cheese with Added Herbs, Spices and Condiments. In: Encyclopedia of Dairy Sciences, Fuquay JW, Fox PF and McSweeney PLH (eds.), Second Edition, Volume. 1, Academic Press, US, pp. 783-789, doi: 10.1016/B978-0-12-374407-4.00507-0

Karasu-Yalcin, S., Senses-Ergul, S., Ozbas, Z.Y. (2012). Identification and enzymatic characterization of the yeasts isolated from Erzincan tulum cheese. Mbjekarstvo. 62(1): 53-61.

Karasu-Yalcin, S., Senses-Ergul, S., Ozbas, Z.Y. (2017). Enzymatic characterization of yeast strains originated from traditional Mihalic cheese. J. Microbiol. Biotechnol. Food Sci. 6(5): 1152-1156, doi: 10.15414/jmbfs.2017.6.5.1152-1156

Kesenkas, H., Akbulut, N. (2008). Yeasts as ripening adjunct cultures in Turkish white brined cheese production. Turk J. Vet. Anim. Sci. 32(5): 327-333.

Kumar, S., Stecher, G., Li, M., Knyaz, C., Tamura, K. (2018). MEGA X: Molecular evolutionary genetics analyses across computing platforms. Mol. Biol. Evol. 35: 1547-1549, doi: 10.1093/molbev/msy096

Kurtzman, C.P., Robnett, C.J. (1998). Identification and phylogeny of ascomycetous yeasts from analysis of nuclear large subunit (26S) ribosomal DNA partial sequences. Anton. Leenn. Int. J. G. 73(4): 331-371, doi: 10.1023/A:1001761008817

Landell, M.F., Hartfelder, C., Valente, P. (2006). Identification and enzymatic profile of yeasts isolated from artisanal cheese in Southern Brazil. Acta Sci. Vet. 34 (1): 49-55.

Lane, M.M., Morrissey, J.P. (2010). Kluyveromyces marxianus: a yeast emerging from its sister's shadow. Fungal Biol.Rev. 24(1-2): 17-26, doi: 10.1016/j.fbr.2010.01.001

Lavoie, K., Touchette, M., St-Gelais, D., Labrie, S. (2012). Characterization of the fungal microflora in raw milk and specialty cheeses of the province of Quebec. Dairy Sci. Technol. 92(5): 455468, doi: 10.1007/s13594-011-0051-4

Lhomme, E., Lattanzi, A., Dousset, X., Minervini, F., De Angelis, M., Lacaze, G., Onno, B., Gobbetti, M. 2015. Lactic acid bacterium and yeast microbiotas of sixteen French traditional sourdoughs. Int. J. Food Microbiol. 215: 161-170, doi: 10.1016/j.ijfoodmicro.2015.09.015

Mathara, J. M., Schillinger, U., Kutima, P. M., Mbugua, S. K., Holzapfel, W.H. (2004). Isolation, identification and characterisation of the dominant microorganisms of kule naoto: the Maasai traditional fermented milk in Kenya. Int.J. Food Microbiol. 94(3): 269-278, doi: 10.1016/j.ijfoodmicro.2004.01.008

McSweeney P.L.H. (2004). Biochemistry of cheese ripening. Int. J. Dairy Technol. 57(2-3): 127144, doi: 10.1111/j.1471-0307.2004.00147.x

Mei, J., Guo, Q., Wu, Y., Li, Y. (2014). Microbial diversity of a Camembert-type cheese using freeze-dried Tibetan kefir coculture as starter 
culture by culture-dependent and cultureindependent methods. PloS one. 9 (10): e111648, doi: 10.1371/journal.pone.0111648

Moon, S.H., Chang, M., Kim, H.Y., Chang, H.C. (2014). Pichia kudriavzevii is the major yeast involved in film-formation, off-odor production, and texture-softening in over-ripened Kimchi. Food Sci. Biotechnol. 23(2): 489-497, doi: 10.1007/s10068-014-0067-7

Ocak, E., Javidipour, I. and Y. Tuncturk. (2015). Volatile compounds of Van Herby cheeses produced with raw and pasteurized milks from different species. Int. J. Food Sci. Tech. 52(7): 43154323, doi: 10.1007/s13197-014-1458-8

Ozer, G., Bayraktar, H. (2018). Genetic diversity of Fusarium oxysporum f. sp. cumini isolates analyzed by vegetative compatibility, sequences analysis of the rDNA IGS region and iPBS retrotransposon markers. J. Plant Pathol. 100 (2): 225-232, doi: 10.1007/s42161-018-0063-5

Padilla, B., Manzanares, P., Belloch, C. (2014). Yeast species and genetic heterogeneity within Debaryomyces hansenii along the ripening process of traditional ewes' and goats' cheeses. Food Microbiol. 38: 160-166, doi: 10.1016/j.fm.2013.09.002

Psomas, E., Andrighetto, C., LitopoulouTzanetaki, E., Lombardi, A., Tzanetakis, N. (2001). Some probiotic properties of yeast isolates from infant faeces and Feta cheese. Int. J. Food Microbiol. 69(1-2): 125-133, doi: 10.1016/S01681605(01)00580-3

Spitaels, F., Wieme, A. D., Janssens, M., Aerts, M., Daniel, H. M., Van Landschoot, A., De Vuyst, L., Vandamme, P. (2014). The microbial diversity of traditional spontaneously fermented lambic beer.
Plos one. 9(4): e95384, doi: 10.1371/journal.pone.0095384

Stepaniak, L. (2004). Dairy enzymology. Int. J. Dairy Technol. 57(2-3): 153-171, doi: 10.1111/j.1471-0307.2004.00144.x

Tamura, K., Nei, M. (1993). Estimation of the number of nucleotide substitutions in the control region of mitochondrial DNA in humans and chimpanzees. Mol. Biol. Evol. 10: 512-526, doi: 10.1093/oxfordjournals.molbev.a040023

Tarakci, Z., Coskun, H. and Tuncturk, Y. (2004). Some Properties of Fresh and Ripened Herby Cheese, a Traditional Variety Produced in Turkey. Food Technol. Biotechno. 42(1): 47-50.

Thompson, J. D., Higgins, D. G., Gibson, T.J. (1994). CLUSTAL W: improving the sensitivity of progressive multiple sequence alignment through sequence weighting, position-specific gap penalties and weight matrix choice. Nucleic Acids Res. 22: 4673-4680, doi: 10.1093/nar/22.22.4673.

Zeng, X., Xia, W., Wang, J., Jiang, Q., Xu, Y., Qiu, Y., Wang, H. (2014). Technological properties of Lactobacillus plantarum strains isolated from Chinese traditional low salt fermented whole fish. Food Control. 40: 351-358, doi: 10.1016/j.foodcont.2013.11.048.

Zheng, X., Li, K., Shi, X., Ni, Y., Li, B., Zhuge, B. (2018). Potential characterization of yeasts isolated from Kazak artisanal cheese to produce flavoring compounds. Microbiology Open 7(1): e00533, doi: 10.1002/mbo3.533. 